Dept. of Animal Medicine, Fac. of Vet. Med., Assiut University, Assiut, Egypt.

Corresponding author: aref71@hotmail.com

\title{
THERAPEUTIC EFFECT OF VITAMIN C IN ENDOTOXIN-INDUCED METABOLIC ACIDOSIS AND OXIDATIVE STRESS IN LAMBS
}

(With 3 Tables and 2 Figures)

\author{
By \\ N-E. M. AREF and M.E. MAHMOUD*
}

* Dept. of Animal Husbandry, Hygiene and Zoonoses, Fac. of Vet. Med., Sohag University, Sohag, Egypt

(Received at 25/1/2011)

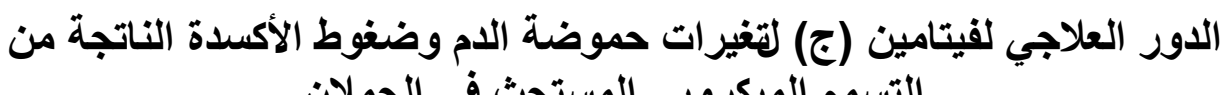
التسمم الميكروبي المستحث في الحملان نصر اللدين محمد محمد عارف ' معتمد السبإ محمود

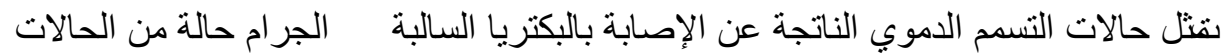

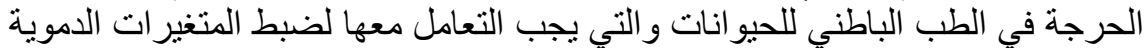

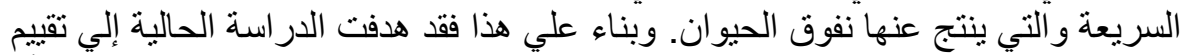

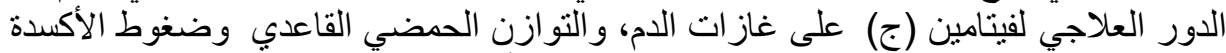

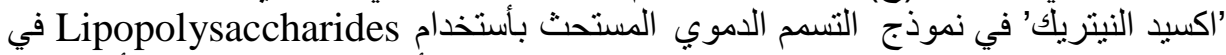

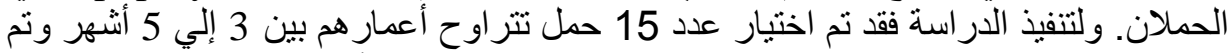

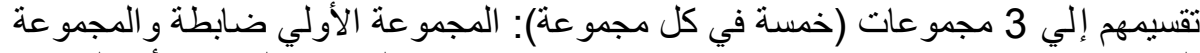

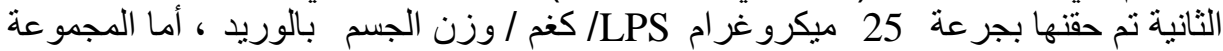

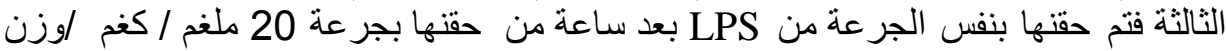

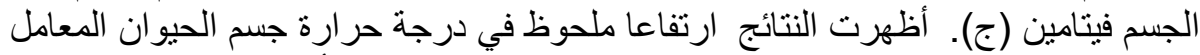

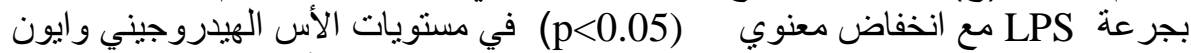

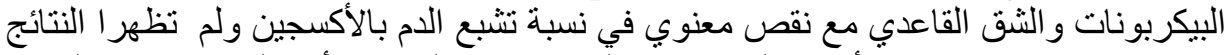

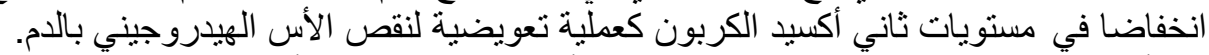

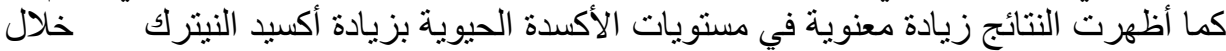

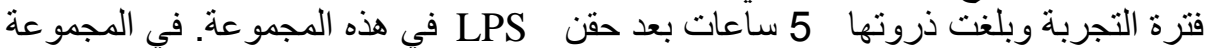

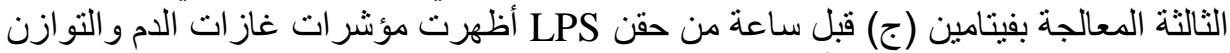

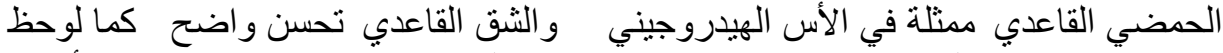

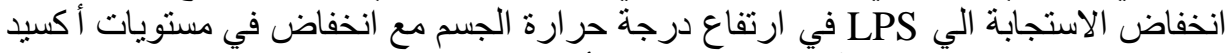

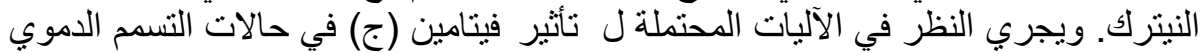

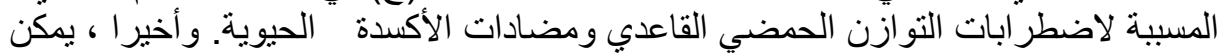




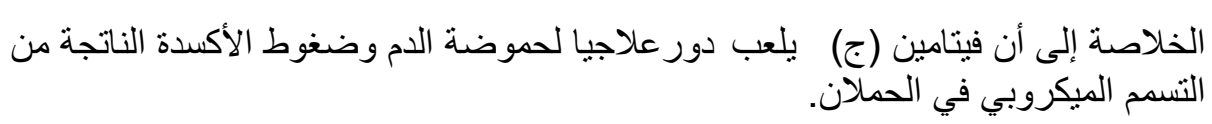

\section{SUMMARY}

Endotoxemia associated with Gram-negative sepsis is an emergency clinical state that causes rapid biochemical changes and substantial mortalities in livestock. The present study aimed to investigate the therapeutic effect of vitamin $\mathrm{C}$ on blood gases, acid-base balance and nitric oxide in lamb model of lipopolysaccharide [LPS]- induced endotoxemia. The study was conducted on 15 lambs, 3-5 months of age. Animals were randomly grouped into 3 groups, five each as followings: Group 1 (control): received only normal saline, Group 2: received only LPS at dose $25 \mu \mathrm{g} / \mathrm{kg}$ B.W. and Group 3: received vitamin C at dose 20 $\mathrm{mg} / \mathrm{kg} \mathrm{B.W}$. one hour before LPS infusion. Saline $(10 \mathrm{ml})$ or LPS in saline were infused through jugular canula. The experimental fever elicited by iv injection of LPS $25 \mu \mathrm{g} / \mathrm{kg} / \mathrm{B}$.W. was accompanied by metabolic acidosis, hypoxemia and significance increased production of nitric oxide. A significant decrease in blood $\mathrm{pH}$, base excess and $\mathrm{HCO}_{3}{ }^{-}$ was noticed during fever. Although the concentrations of $\mathrm{HCO}_{3}{ }^{-}$were decreasing till the end of the experiment, there was no substantial falls in $\mathrm{PCO}_{2}$ for compensation of the noticed acidosis. However, hypoxemia was evident as indicated with marked reduction in oxygen saturation and oxygen tension. Nitric oxide level increased during the period of experiment and reached peak 5 hours post LPS administration. Pretreatment with i.v. $20 \mathrm{mg} / \mathrm{kg} \mathrm{B.W}$. of vitamin C an hour pre LPS administration reduced the febrile response and reversed the postpyrogen changes in $\mathrm{pH}, \mathrm{HCO}_{3}{ }^{-}$and nitric oxide. Possible mechanisms by which vitamin $\mathrm{C}$ could affect the LPS-induced disturbances of acid-base balance are being considered. Finally, it could be concluded that vitamin $\mathrm{C}$ pretreatment prevented LPS -induced metabolic acidosis and nitric oxide production.

Keywords: Vitamin C, lipopolysaccharide, Acidosis, Fever, Nitric Oxide.

\section{INTRODUCTION}

Endotoxemia associated with Gram-negative sepsis is a clinical systemic state caused by widespread activation of host defense mechanisms to the presence of endotoxins (lipopolysaccharide [LPS]) (Radostits et al., 2006). In veterinary practice, the endotoxins of several 
species of Gram-negative bacteria are a major cause of morbidity and mortality in farm animals (Cullor, 1992) including sheep (Daudel et al., 2006). While there is no exact monitory figure on the actual amount of financial losses due to endotoxemia, diseases characterized by toxemia such as inflammatory conditions, (pneumonia, pleuritis, enteritis, pericarditis, etc..) are common and cause severe economic losses. The standard known endotoxins are those of $E$. coli, which causes coliform septicemia in newborn farm animals and have been used extensively as models for experimental endotoxemia (Radostits et al., 2006; Lubbers et al., 2010). The pathophysiology of endotoxemia is extensively reviewed (Morris, 1991; Cullor, 1992; Olson et al., 1992; Roy, 2004; Sykes and Furr, 2005). The intense release of pro inflammatory cytokines due to inappropriate activation of wide range of host defense cells in response to LPS exposure culminates in multiple-organ dysfunction and failure in animals (Hukkanen et al., 2009). An alteration in cellular oxygen metabolism (oxidative stress) and excessive production of nitric oxide (NO) have also been implicated in the pathogenesis of endotoxemia in animals (Parratt, 1997; Titheradge, 1999; Vanasco et al., 2008). In sepsis, LPS induces inducible nitric oxide synthase (iNOS) expression leading to sustained release of $\mathrm{NO}$ in mammals (Cadenas and Cadenas, 2002; Fortin et al., 2010). NO is a potent vasodilator and its continuous overproduction during the course of endotoxemia, along with the production of various cytokines, leads to vasodilatation and hypotension (Kalokerinos et al., 2005; OliveiraPelegrin et al., 2010). Decreased skin perfusion and immobility, behavioral despair and reduced mental alertness are among characteristic signs of LPS -induced endotoxemia (Zhu et al., 2010).

The clinical problems associated with endotoxemia, gastrointestinal disturbances, marked alterations in cardiopulmonary function, coagulopathies, heart and renal failure and shock (Gullo, 1999; Radostits et al., 2006) present many challenges for designing a suitable therapeutic regime beyond the proper selection of antibiotics. Although antimicrobial agents often clear the bloodstream rapidly of viable bacteria, sequelae of endotoxemia may lead to death (Young et al., 1977; Bryan et al., 1983). Furthermore, bacteriocidal drugs have the potential for releasing endotoxin from the massive destruction of Gram-negative bacteria (Horii et al., 2000; Radostits et al., 2006) and worsening the outcome. Against this background, there is an urgent need to define proper therapeutic approaches that could ameliorate the effect of endotoxemia and pave the way for the safety use of antimicrobial 
therapy. Recent insights into the oxidative metabolic effects of endotoxemia (Kalokerinos et al., 2005), antioxidants may provide suitable therapeutic avenues. It is anticipated that antioxidants theoretically should be able to attenuate and block the effects of multiple steps in LPS signaling (Escames et al., 2006). To test this hypothesis, an animal model of LPS-induced toxic effects is developed for investigating the possible antagonistic effect of vitamin $\mathrm{C}$, powerful antioxidant, by measuring standard blood gas parameters, hemogarm and nitric oxide.

\section{MATERIALS and METHODS}

\section{Animals:}

The study was conducted on 15 lambs, 3-5 months of age and 18 $\pm 5 \mathrm{~kg} \mathrm{~B}$.W. in the Veterinary Teaching Hospital, Faculty of Veterinary Medicine, Assiut University, Assiut- Egypt. The animals were clinically healthy, showed no signs of distress, kept at ambient temperature of $21.5 \pm 0.5^{\circ} \mathrm{C}$ and $60-70 \% \mathrm{RH}$. Lambs are reared under satisfactory standards of animal management and feeding. Animals were randomly grouped into 3 groups, five each as followings: Group 1 (control): received only normal saline, Group 2: received only LPS (Sigma Chemical Company St. Louis Mo, USA) at dose $25 \mu \mathrm{g} / \mathrm{kg} \mathrm{B.W}$. and Group 3: received vitamin $\mathrm{C}$ at dose $20 \mathrm{mg} / \mathrm{kg} \mathrm{B.W}$. one hour before LPS infusion. Saline $(10 \mathrm{ml})$ or LPS in saline were infused through jugular canula. The experiments complied with the guidelines and recommendations for the Institutional Animal Care and Use Committee of Assiut University.

\section{Clinical parameters:}

Body temperature, pulse rate, and oxygen saturation were digitally recorded using pulse oximeter for veterinary use (Model 340V, CA-USA). The behavior and mental status of animals were monitored by inspection.

\section{Blood sampling:}

\subsection{Heparinized whole blood samples:}

Five $\mathrm{ml}$ of blood was collected by means of jugular vein puncture from each lamb into sterile plastic syringes whose dead spaces had previously filled with heparin 1: 1000 I.U. / ml. The presence of air bubbles in syringes was restrictly avoided and the tips of needles were sealed immediately by its plastic covers. These samples were 
immediately placed on ice bath to avoid the metabolic changes in the blood. Collected samples were used for analysis of blood gases and acid - base balance directly within 30 minutes from sampling and then subsequently used for complete blood picture (CBC) evaluation.

\subsection{Serum sample:}

Blood samples were collected in clean, dry centrifuge tubes without anticoagulant. The samples were left for 30 minutes at room temperature until clotting and then centrifuged at $3000 \mathrm{rpm}$ for 20 minutes (Coles and Rich, 1992). The obtained clear non hemolyzed sera were separated and transferred into clean epindorff vials and then stored at $-20{ }^{\circ} \mathrm{C}$ for determination of nitric oxide.

Blood samples were taken at three different set points: 1, 3 and 5 hours after the onset of experiment in three groups.

\section{Bioassay:}

\subsection{Blood Gases and acid-base balance:}

Blood gases and acid-base balance parameters were measured using ABL5 Blood Gas Analyser (Radiometer, Denmark). The machine was calibrated and subjected to test of quality control before assay. The blood samples were thoroughly mixed before analysis and the first drops of blood were discarded. The syringe nozzle was fitted in the apparatus probe and the blood was aspirated automatically.

\subsection{Complete blood picture (CBC) assessment:}

Total red blood cell count (TRBCs- T/l), hemoglobin concentration (Hb-g/l), packed cell volume (PCV\%), total and differential leuckocytic counts (TWBSc- G/l and DLC-G/l) were determined using a fully automated blood cell counter machine, Medonic CA620 Vet hematology analyzer -Sweden.

\subsection{Nitric oxide determination:}

NO in biological systems was measured indirectly by reaction kinetics according to (Green et al., 1982) using Griess diazotization reaction to spectrophotometrically detect nitrite formed by the spontaneous oxidation of NO under physiological conditions. The detection of NO using Griess reagent (Sigma chemical company St. Louis Mo, USA) was preformed by the method of microplate assay. Briefly: equal amounts (50 ul) of serum sample and Griess reagent were mixed in each well of microplate. The plate was incubated for 15 minutes at room temperature. A photometric reference sample was prepared by mixing equal amounts of Griess reagent and deionized 
water. The absorbance of the nitrite-containing samples relative to the reference sample was measured in a spectrophotometric microplate reader (StatFax-2100, Awareness, Technology Inc.). The optimum measurement wavelength was $540 \mathrm{~nm}$. Standard curve for different concentration of nitrite solution was preformed for calculation of the NO concatenation using sodium nitrite solutions (Sigma chemical company St. Louis Mo, USA) with concentrations between 1-100 $\mu \mathrm{M}$. The absorbance measurements of standard nitrite solutions were recorded as described above in place of the experimental samples. A standard curve of nitrite concentration (x-axis) against absorbance (y-axis) was plotted and nitrite concentrations corresponding to the absorbance of experimental samples were obtained from the standard plot. The total NO concentration was expressed in micromolar concentrations.

\section{Statistical analysis}

Data were analyzed using the packaged SPSS program for windows version 10.0.1 (SPSS Inc., Chicago, IL). All data were presented as mean \pm standard deviation (SD). Differences between groups were determined by LSD Post hoc test. Significance level was set at $\mathrm{P} \leq 0.05$.

\section{RESULTS}

\section{Clinical signs:}

Treatment of lambs with $25 \mu \mathrm{g}$ of LPS per $\mathrm{Kg}$ body weight had $0.5^{\circ} \mathrm{C}$ increase in rectal temperature, within 1 hour of LPS infusion $(\mathrm{P} \leq 0.05)$. Animals received endotoxin had a single temperature peak three-hour post LPS administration $\left(1.13^{\circ} \mathrm{C}\right.$ differences). Furthermore, the final differences in temperature between control and LPS-treated animals were statistically significant during 5 hours post LPS administration $(\mathrm{P} \leq 0.05)$. The sign of pyrexia was evident and LPS treated lambs showed various degrees of mental depression, shallow and rapid respiration and dryness of the mouth and muzzle. While pulse oximeter recorded an increase in the pulse rate $(110 \pm 8.0$ beats/minute), a decrease in oxygen saturation was noticed (Table 1). Pretreatment of lambs with vitamin $\mathrm{C}$ appeared to diminish the febrile response to endotoxin administration, as they showed no significant difference in body temperature versus control group (Fig. 1).

\section{Hematological analysis}


LPS group showed a significant decrease in TWBCs and they became leucopenic with neutropenic 1 and 3 hours post LPS administration ( $\mathrm{P}<0.05$; Table 2 ), with $63.63 \%$ and $30.90 \%$ declines in leukocyte and granylocytic counts respectively. Erythrocyte indices showed no statistically difference among groups. Pretreated group with vitamin $\mathrm{C}$ showed marked improvement in the total lecuocytic and granulocytic counts (Table 2).

\section{Blood Gases and Acid-Base Balance}

Venous blood gas data are listed in Table 3. Statistical analysis of these data revealed significant trends or differences in responses among groups. Group that received LPS only showed mild acidosis as the blood $\mathrm{pH}$ fall from $7.39 \pm 0.01$ to $7.33 \pm 0.03$ one hour post LPS infusion $(\mathrm{P} \leq 0.05)$. Reduction in blood $\mathrm{pH}$ continued up to $7.30 \pm 0.01$ five hours after LPS administration. The laboratory indices of metabolic side of acid-base disturbance: base excess, bicarbonate and total carbone dioxide, showed significant reduction in their values, however the $\mathrm{pCO}_{2}$ value showed no significant difference. In addition to, marked reduction in oxygen saturation and oxygen tension and thus hypoxemia were evident in LPS administrated group. On the other hand, there was no such alteration in acid base balance indices in pretreated group with vitamin C (Table 3 ).

\section{Nitric oxide production}

Nitrite levels in serum was significantly $(\mathrm{P} \leq 0.05)$ increased 5 hours after LPS administration in lambs while no such increase was observed in pretreated group with vitamin C (Fig. 2).

Table 1: Mean values $( \pm \mathrm{SD})$ of clinical indices in control, LPS and pretreated LPS groups

\begin{tabular}{|c|c|c|c|c|c|c|c|}
\hline \multirow{2}{*}{ Parameter } & \multirow{2}{*}{$\begin{array}{l}\text { Control } \\
\text { (saline } \\
\text { only) }\end{array}$} & \multicolumn{3}{|c|}{ LPS Only } & \multicolumn{3}{|c|}{ Pretreated LPS with vit. C } \\
\hline & & $1 \mathrm{hr}$ & $3 \mathrm{hrs}$ & $5 \mathrm{hrs}$ & $1 \mathrm{hr}$ & $3 \mathrm{hrs}$ & $5 \mathrm{hrs}$ \\
\hline $\begin{array}{l}\text { Temperature } \\
\left({ }^{\circ} \mathrm{C}\right)\end{array}$ & $\begin{array}{c}39.80 \pm \\
0.10\end{array}$ & $\begin{array}{c}40.30 \pm \\
0.52\end{array}$ & $\begin{array}{c}40.93 \pm \\
0.12\end{array}$ & $\begin{array}{c}40.40 \pm \\
0.10\end{array}$ & $\begin{array}{c}39.60 \pm \\
0.61\end{array}$ & $\begin{array}{c}39.83 \pm \\
0.67\end{array}$ & $\begin{array}{c}39.90 \pm \\
0.56\end{array}$ \\
\hline $\begin{array}{l}\text { Pulse } \\
\text { (beats/min) }\end{array}$ & $93 \pm 5$ & $112 \pm 8.0$ & $116 \pm 7$ & $110 \pm 6$ & $100 \pm 4.0$ & $100 \pm 7$ & $94 \pm 5$ \\
\hline $\mathrm{O}_{2}$ Sat. & $\begin{array}{c}78.24 \pm \\
5.28\end{array}$ & $\begin{array}{c}54.67 \pm \\
6.66 *\end{array}$ & $\begin{array}{c}60.00 \pm \\
7.00^{*}\end{array}$ & $\begin{array}{c}61.98 \pm \\
4.76^{*}\end{array}$ & $\begin{array}{c}60.00 \pm \\
12.00\end{array}$ & $\begin{array}{c}62.67 \pm \\
9.96\end{array}$ & $\begin{array}{c}74.67 \pm \\
8.96\end{array}$ \\
\hline
\end{tabular}


Table 2: Mean values $( \pm$ SD) of Leucocytes indices in control, LPS and pretreated LPS groups

\begin{tabular}{|c|c|c|c|c|c|c|c|}
\hline \multirow{2}{*}{ Parameter } & \multirow{2}{*}{$\begin{array}{l}\text { Control } \\
\text { (saline } \\
\text { only) }\end{array}$} & \multicolumn{3}{|c|}{ LPS Only } & \multicolumn{3}{|c|}{ Pretreated LPS with vit. C } \\
\hline & & $1 \mathrm{hr}$ & $3 \mathrm{hrs}$ & $5 \mathrm{hrs}$ & $1 \mathrm{hr}$ & $3 \mathrm{hrs}$ & $5 \mathrm{hrs}$ \\
\hline TWBCs $(\mathrm{G} / \mathrm{l})$ & $\begin{array}{c}11.31 \pm \\
1.54\end{array}$ & $\begin{array}{l}7.63 \pm \\
0.81 *\end{array}$ & $\begin{array}{l}8.73 \pm \\
0.71 *\end{array}$ & $\begin{array}{c}10.30 \pm \\
0.20\end{array}$ & $\begin{array}{c}9.39 \pm \\
2.74\end{array}$ & $\begin{array}{c}10.99 \pm \\
1.98\end{array}$ & $\begin{array}{c}10.38 \pm \\
2.04\end{array}$ \\
\hline \multicolumn{8}{|l|}{ DLC (G/l) } \\
\hline Granulocyte & $\begin{array}{c}4.53 \pm \\
1.61\end{array}$ & $\begin{array}{l}1.40 \pm \\
0.20^{*}\end{array}$ & $\begin{array}{l}2.40 \pm \\
0.12 *\end{array}$ & $\begin{array}{c}3.09 \pm \\
0.20\end{array}$ & $\begin{array}{c}3.04 \pm \\
0.28\end{array}$ & $\begin{array}{c}3.90 \pm 0 . \\
38\end{array}$ & $\begin{array}{c}3.50 \pm \\
0.50\end{array}$ \\
\hline Lymphocytes & $\begin{array}{c}5.66 \pm \\
1.55\end{array}$ & $\begin{array}{c}5.03 \pm \\
1.29\end{array}$ & $\begin{array}{c}6.34 \pm \\
2.07\end{array}$ & $\begin{array}{c}5.90 \pm \\
0.98\end{array}$ & $\begin{array}{c}5.39 \pm \\
2.29\end{array}$ & $\begin{array}{c}4.94 \pm \\
1.96\end{array}$ & $\begin{array}{c}4.83 \pm \\
1.89\end{array}$ \\
\hline Monocytes & $\begin{array}{c}1.12 \pm \\
0.45\end{array}$ & $\begin{array}{c}1.20 \pm \\
1.15\end{array}$ & $\begin{array}{c}0.89 \pm \\
0.10\end{array}$ & $\begin{array}{c}0.96 \pm \\
0.18\end{array}$ & $\begin{array}{c}1.21 \pm \\
1.05\end{array}$ & $\begin{array}{c}1.30 \pm \\
1.01\end{array}$ & $\begin{array}{c}1.20 \pm \\
0.95\end{array}$ \\
\hline
\end{tabular}

Table 3: Mean values $( \pm \mathrm{SD})$ of Blood Gas and Acid-Base Status in control, LPS and pretreated LPS groups

\begin{tabular}{|l|c|c|c|c|c|c|c|}
\hline \multirow{4}{*}{ Parameter } & \multirow{2}{*}{$\begin{array}{c}\text { Control } \\
\text { (saline } \\
\end{array}$} & \multicolumn{4}{|c|}{ LPS Only } & \multicolumn{2}{c|}{ Pretreated LPS with vit. C } \\
\cline { 3 - 8 } & only) & $1 \mathrm{hr}$ & $3 \mathrm{hrs}$ & $5 \mathrm{hrs}$ & $1 \mathrm{hr}$ & $3 \mathrm{hrs}$ & $5 \mathrm{hrs}$ \\
\hline $\mathrm{pH}$ & $7.39 \pm$ & $7.33 \pm$ & $7.30 \pm$ & $7.30 \pm$ & $7.38 \pm$ & $7.40 \pm$ & $7.44 \pm$ \\
& 0.01 & $0.03^{*}$ & $0.02^{*}$ & $0.01^{*}$ & 0.02 & 0.06 & 0.08 \\
\hline $\mathrm{PCO}_{2}$ & $43.40 \pm$ & $48.67 \pm$ & $43.50 \pm$ & $45.68 \pm$ & $45.33 \pm$ & $43.67 \pm$ & $34.67 \pm$ \\
& 4.29 & 3.09 & 5.50 & 3.02 & 2.49 & 2.05 & 2.05 \\
\hline $\mathrm{PO}_{2}$ & $40.60 \pm$ & $31.67 \pm$ & $35.00 \pm$ & $32.20 \pm$ & $37.67 \pm$ & $39.33 \pm$ & $40.33 \pm$ \\
& 3.37 & $4.78^{*}$ & $6.00^{*}$ & 3.50 & 2.49 & 4.19 & 3.58 \\
\hline $\mathrm{HCO}_{3}$ & $24.13 \pm$ & $22.00 \pm$ & $20.50 \pm$ & $20.90 \pm$ & $23.67 \pm$ & $25.67 \pm$ & $26.67 \pm$ \\
& 1.18 & $2.94^{*}$ & $2.50^{*}$ & $1.30^{*}$ & 1.25 & 3.40 & 3.40 \\
\hline $\mathrm{tCO}_{2}$ & $25.76 \pm$ & $26.33 \pm$ & $23.00 \pm$ & $22.98 \pm$ & $24.33 \pm$ & $27.67 \pm$ & $29.67 \pm$ \\
& 1.86 & $1.25^{*}$ & $2.94^{*}$ & $2.85^{*}$ & 1.25 & 3.25 & 3.12 \\
\hline $\mathrm{BE}^{*}$ & $-1.6 \pm$ & $-4.00 \pm$ & $-9.00 \pm$ & $-8.0 \pm$ & $+1.90 \pm$ & $+2.00 \pm$ & $+3.00 \pm$ \\
& 0.68 & $0.35^{*}$ & $2.12^{*}$ & $1.98^{*}$ & 0.89 & 0.96 & 1.07 \\
\hline
\end{tabular}

* significant at $\mathrm{p} \leq 0.05$ 


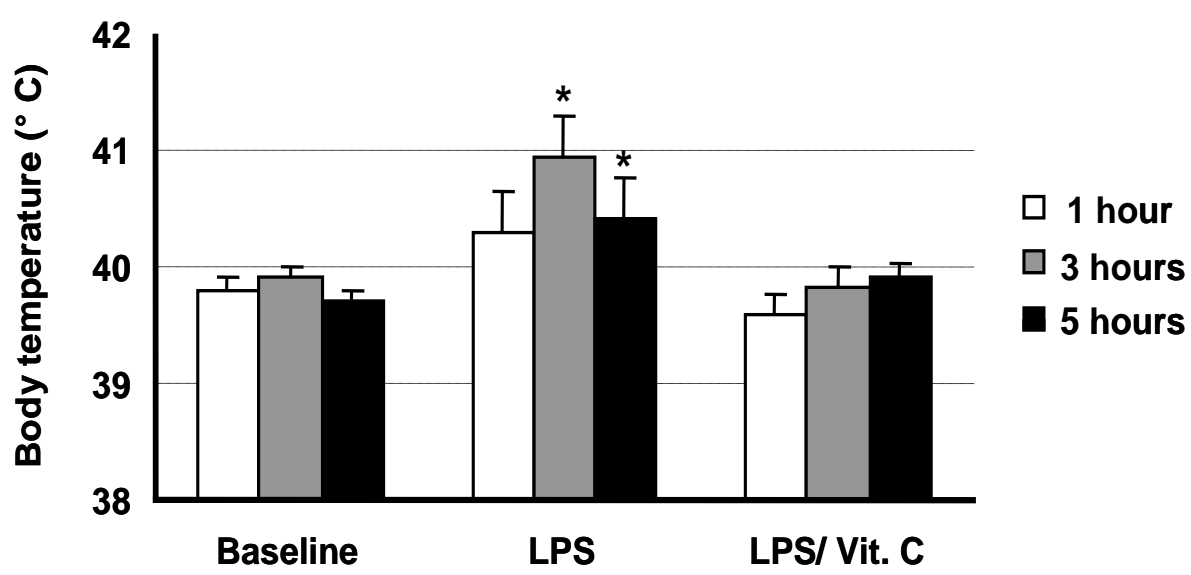

Fig. 1: Effect of 1 hour pretreatment with Vitamin C (20 mg/kg.bwt, iv.) on body temperature at 1, 3 and 5 hours after injection with LPS (25 $\mu \mathrm{g} / \mathrm{kg}$.bwt. iv) in sheep. Data are presented as mean \pm SD. Results are compared with baseline from control saline injected lambs. Each value represents the mean \pm SD of triplicates of one representative experiment.

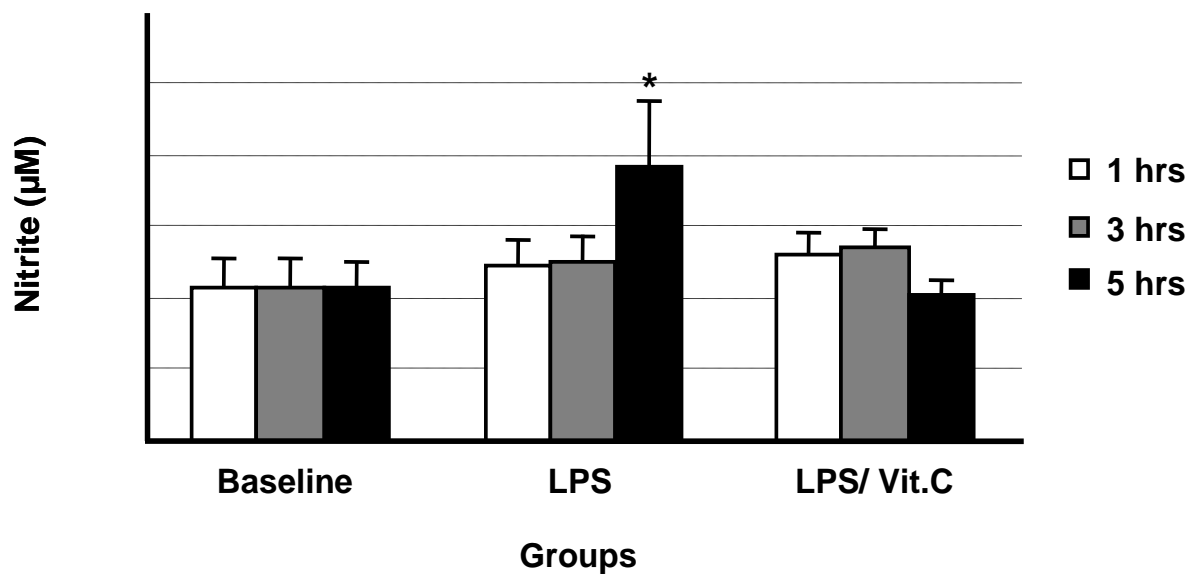

Fig. 2: Effect of 1 hour pretreatment with Vitamin C (20 mg/kg.bwt, iv.) on serum nitrite level at 1 and 5 hours after injection with LPS (25 $\mu \mathrm{g} / \mathrm{kg}$.bwt.) in sheep. Data are presented as mean $\pm \mathrm{SD}$ of nitrite at 1 and 5 hours measurement. Results are compared with baseline from control saline injected animals. Each value represents the mean \pm SD of triplicates of one representative experiment. 


\section{DISCUSSION and CONCLUSION}

LPS-induced toxic effects were clearly observed in our experiment. Disturbance in thermoregulatory center, acid-base balance and oxidation process were recorded. A rise in body temperature was shown in LPS administered group, which is considered as a cardinal signs of endotoxemia. LPS is a potent stimulators of cytokines production, key mediators of endotoxemia, which participates in the acute phase response of endotoxemia that are characterized by fever, disturbed blood $\mathrm{pH}$, reduced tissue oxygen saturation, lowered blood pressure, disseminated intravascular coagulation that may end in shock (Green and Adams, 1992; Tsiotou et al., 2005; Hukkanen et al., 2009).

Disturbance in acid-base balance (metabolic acidosis) in response to LPS administration was a consistent finding in our experiment. A significant reduction in blood $\mathrm{pH}$ and an increase in the total acid load as shown by decreased standard base excess (Table 3) in LPS-injected group were recorded. Although the concentrations of $\mathrm{HCO}_{3}{ }^{-}$were decreasing till the end of the experiment, there was no falls in $\mathrm{pCO}_{2}$ for compensation of the noticed acidosis. Marked reductions in oxygen saturation, oxygen tension, indicating tissue hypoxia were evident after LPS injection. These findings were in an agreement with previously conducting experiments on sheep and pig models (Moore et al., 1980 and 1981; Knotzer et al., 2006). The mechanism by which LPS induces metabolic acidosis is not well established however many review articles suggests the possible role of lactic acid production during the course of endotoxemia (Moore et al., 1980 and 1981). Lactic acidosis is usually associated with hypoxia related to decreased tissue perfusion, a marked increases in tissue oxygen demand or reduced blood oxygen content. Moreover, in rare instances, lactic acidosis may be associated not only with hypoxia but also with abnormal mitochondial oxidative function due to drug or toxin (Vanasco et al., 2008). Thus, both ways could be incriminated in the production of metabolic acidosis in our experiment.

Our data (Fig. 2) also showed a significant increase in NO, reactive nitrogen species (RNS), production in response to LPS administration. The uncontrolled production of cytokines during endotoxemia produce overwhelming amounts of reactive oxygen species (ROS) and reactive RNS, leading to free radical production and catastrophic tissue damage (De Angelo, 1999; Kalokerinos et al., 2005; O'Brien et al., 2009). 
Pretreatment of lambs with vitamin $\mathrm{C}$ reduced fever, correct metabolic acidosis and minimizes oxidative stress following a potentially lethal endotoxin challenge. It has been reported that vitamin C "neutralizes" or "detoxifies" the deleterious effects of endotoxin (Ashton et al., 2003). Vitamin C has many diverse biological functions since it influences numerous enzyme activities. Importantly, it acts as an antioxidant which efficiently scavenges reactive oxygen intermediates (ROI) outside and within cells (Ames et al., 1993; Wu et al., 2003). In a porcine blood cell experiment, vitamin $\mathrm{C}$ interferes with the reactive oxygen intermediates. After activation of polymorphonuclear leukocytes (PMNL), vitamin C - depleted PMNL display a markedly higher oxidative burst than PMNL containing normal physiological vitamin C levels (Schwager and Schulze, $1998 \mathrm{a}$ and b). Therefore, antioxidants presumably contribute to maintain cellular integrity by quenching ROI (Hemilā et al., 1984).

Vitamin C may work via controlling the flow-on effects of endotoxin signaling (Kalokerinos et al., 2005). High amount of antioxidants are required in sustained concentrations to both prevent and combat the effect of endotoxemia. By far the safest, cheapest, easiest to sustain and easiest to administer effective antioxidant is vitamin $\mathrm{C}$ which can be safely given intravenously in tens of grams over multiple doses (De Angelo, 1999; Pleiner et al., 2002).

In conclusion, vitamin $\mathrm{C}$ prevents the deterioration of acid base homostasis and overcome the free radicals and NO production in endotoxemia in LPS animal model. Therefore, vitamin $\mathrm{C}$ may have therapeutic implications and important clinical application for animals at high risk for the development of lifethreatening toxemia or in conditions, which generate free radical stress.

\section{ACKNOWLEDGMENT}

This work was supported by scientific research fund of Assiut University, Egypt.

\section{Conflict of interest}

There is no conflict of interest 


\section{REFERENCES}

Ames, B.N.; Shigenaga, M. and Hagen, T.M. (1993): Oxidants, antioxidants, and the degenerative diseases of aging. Proc. Natl. Acad. Sci. (USA) 90: 7915-7922.

Ashton, T.; Young, I.S.; Davison, G.W.; Rowlands, C.C.; McEneny, J.; Van Blerk, C.; Jones, E.; Peters, JR. and Jackson, S.K. (2003): Exercise-induced endotoxemia: the effect of ascorbic acid supplementation. Free Radic Biol Med. Aug 3: 284-291.

Bryan, C.S.; Reynolds, K.L. and Brenner, E.R. (1983): Analysis of 1,186 episodes of gram-negative bacteremia in non-university hospitals: the effects of antimicrobial therapy. Rev. Infect. Dis. 5: 629-638.

Coles, E.H. and Rich, L.J. (1992): Veterinary Laboratory Medicine. WB Saunders Co, Philadelphia, Pennsylvania, USA. 1st edn.. ISBN 0-7216-2654-8.

Cadenas, S. and Cadenas, A.M. (2002): Fighting the stranger antioxidant protection against endotoxin toxicity. Toxicology. 1: 45-63.

Cullor, J.S. (1992): Shock attributable to bacteremia and endotoxemia in cattle: clinical and experimental findings. J. Am. Vet. Med. Assoc. 200: 1894-1902.

Daudel, F.; Bone, H.G.; Traber, D.L.; Stubbe, H.D.; Lettau, M.; Lange, M.; Scharte, M.; Van Aken, H. and Westphal, M. (2006): Effects of thoracic epidural anesthesia on hemodynamics and global oxygen transport in ovine endotoxemia. Shock. 26: 615-619.

De Angelo, J. (1999): Nitric oxide scavengers in the treatment of shock associated with systemic inflammatory response syndrome. Expert Opin Pharmacother. 1: 19-29.

Escames, G.; López, L.C.; Ortiz, F.; Ros, F.E. and Acuña-Castroviejo, D. (2006): Age-dependent lipopolysaccharide-induced iNOS expression and multiorgan failure in rats: effects of melatonin treatment. Exp Gerontol. 41: 1165-1173.

Fortin, C.F.; McDonald, P.P.; Fülöp, T. and Lesur, O. (2010): Sepsis, leukocytes, and nitric oxide (NO): an intricate affair. Shock. 33: 344-352.

Green, E.M. and Adams, H.R. (1992): New perspectives in circulatory shock: patho- physiological mediators of mammalian response to endotoxemia and sepsis. J. Am. Vet. Med. Assoc. 200: 1834-1841. 
Green, L.C.; Wagner, D.A.; Glogowski, J.; Skipper, P.L.; Wishnok, J.S. and Tannenbaum, S.R. (1982): Analysis of nitrate, nitrite, and $\left[{ }^{15} \mathrm{~N}\right]$ nitrate in biological fluids. Anal. Biochem. 1: 131-138.

Gullo, A. (1999): Sepsis and organ dysfunction/failure. An overview. Minerva Anestesiol. 65: 529-540.

Hemilä, H.; Roberts, P. and WikstrÖm, M. (1984): Activated polymorphonuclear leucocytes consume vitamin C. FEBS Letters 178: 25-30.

Horii, T.; Kimura, T.; Nadai, M. and Kobayashi, M. (2000): Lincomycin-induced endotoxin release in Escherichia coli sepsis: evidence for release in vitro and in vivo. Int. J. Infect. Dis. 3: 118-22.

Hukkanen, R.R.; Liggitt, H.D.; Murnane, R.D. and Frevert, C.W. (2009): Systemic inflammatory response syndrome in nonhuman primates culminating in multiple organ failure, acute lung injury, and disseminated intravascular coagulation. Toxicol Pathol. 37: 799-804

Kalokerinos, A.; Dettman, I. and Meakin, C. (2005): Endotoxin and Vitamin C Part 1 - Sepsis, Endotoxin and Vitamin C. J. Aust. Coll. Nutr. and Env. Med. 1: 17-21

Knotzer, H.; Maier, S.; Dünser, MW.; Hasibeder, WR.; Hausdorfer, H.; Brandner, J.; Torgersen, C.; Ulmer, H.; Friesenecker, B.; Iannetti, C. and Pajk, W. (2006): Arginine vasopressin does not alter mucosal tissue oxygen tension and oxygen supply in an acute endotoxemic pig model. Intensive Care Med. 32: 170-174.

Lubbers, T.; De Haan, J.J.; Hadfoune, M.; Zhang, Y.; Luyer, M.D.; Grundy, D.; Buurman, W.A. and Greve, J.W. (2010): Lipidenriched enteral nutrition controls the inflammatory response in murine Gram-negative sepsis. Crit Care Med. 38: 19962002.

Morris, D.D. (1991): Endotoxemia in horses. A review of cellular and humoral mediators involved in its pathogenesis. J. Vet. Intern. Med. 5: 167-181.

Moore, J.N.; Garner, H.E.; Shapland, J.E. and Hatfield, DG. (1980): Lactic acidosis and arterial hypoxemia during subletal endotoxemia in conscious ponies. Am J Vet Res. 10: 1696-1698.

Moore, J.N.; Garner, H.E.; Shapland, J.E. and Hatfield, DG. (1981): Prevention of endotoxin-induced arterial hypoxemia and lactic acidosis with flunixin meglumine in the conscious pony. Equine Vet. J. 2: 95-98 
O'Brien, A.; Stidwill, RP.; Clapp, LH. and Singer, M. (2009): Variable effects of inhibiting iNOS and closing the vascular ATP-sensitive potassium channel (via its pore-forming and sulfonylurea receptor subunits) in endotoxic shock. Shock. 31: 535-541.

Oliveira-Pelegrin, G.R.; Branco, L.G. and Rocha, M.J. (2010): Central NO-cGMP pathway in thermoregulation and survival rate during polymicrobial sepsis. Can J Physiol Pharmacol. 88: 113-120

Olson, N.C.; Kruse-Elliott, K.T. and Dodam, JR. (1992): Systemic and pulmonary reactions in swine with endotoxemia and Gramnegative bacteremia. J. Am. Vet. Med. Assoc. 200: 1870-1884.

Parratt, JR. (1997): Nitric oxide. A key mediator in sepsis and endotoxaemia? J. Physiol. Pharmacol. 4: 493-506.

Pleiner, J.; Mittermayer, F.; Schaller, G.; MacAllister, R.J. and Wolzt, M. (2002): High doses of vitamin C reverse Escherichia coli endotoxin-induced hyporeactivity to acetylcholine in the human forearm. Circulation. 12: 14601464.

Radostits, O.M.; Gay, C.C.; Hinchcliff, K.W. and Constable, P.D. (2006): A textbook of the diseases of cattle, horses, sheep, pigs and goats, $10^{\text {th }}$ Ed. Saunders Elsevier, Edinburgh London New York Oxford Philadelphia St Louis Sydney Toronto pp 53-60.

Roy, M. (2004): Sepsis in adults and foals. Vet. Clin. North Am. Equine Pract. 20: 41-61.

Schwager, J. and Schulze, J. (1998a): Dependence of growth, bone metabolism and functions of polymorphonuclear leukocytes on ascorbic acid in pigs. Int. J. Vitam. Nutr. Res. 68: 48-58.

Schwager, J. and Schulze, J. (1998b): Modulation of interleukin production by ascorbic acid. Veterinary Immunology and Immunopathology 64: 45-57

Sykes, B.W. and Furr, M.O. (2005): Equine endotoxemia - a state of the art review of therapy. Aust. Vet. J. 83: 45-50.

Titheradge, M.A. (1999): Nitric oxide in septic shock. Biochim. Biophys. Acta. 1411: 437-455.

Tsiotou, A.G.; Sakorafas, G.H.; Anagnostopoulos, G. and Bramis, I. (2005): Septic shock; current pathogenetic concepts from a clinical perspective. Medical Science Monitor: International Medical Journal of experimental and clinical research. 11, RA7685. 
Vanasco, V.; Cimolai, M.C.; Evelson, P. and Alvarez, S. (2008): The oxidative stress and the mitochondrial dysfunction caused by endotoxemia are prevented by alpha-lipoic acid. Free Radic Res. 42: 815-23.

Wu, F.; Wilson, J.X. and Tyml, K. (2003): Ascorbate inhibits iNOS expression and preserves vasoconstrictor responsiveness in skeletal muscle of septic mice. Am. J. Physiol Regul Integr Comp Physiol.1: R50-56.

Young, L.S.; Martin, W.J.; Meyer, R.D.; Weinstein, R.J. and Anderson, E.T. (1977): Gram-negative rod bacteremia: microbiologic, immunologic, and therapeutic considerations. Ann. Intern. Med. 86: 456-471.

Zhu, C.B.; Lindler, K.M.; Owens, A.W.; Daws, L.C.; Blakely, R.D. and Hewlett, W.A. (2010): Interleukin-1 Receptor Activation by Systemic Lipopolysaccharide Induces Behavioral Despair Linked to MAPK Regulation of CNS Serotonin Transporters. Neuropsychopharmacology. 8: 1010-1038. 